\title{
Comparative Study of Phytochemical Contents of Various Mango (Mangifera indica L.) Cultivars of Bihar
}

\author{
Varsha Kumari ${ }^{*}$, Birendra Kumar ${ }^{2}$, Navneet Sinha ${ }^{3}$, Shivadhar Sharma ${ }^{4}$ \\ 1,3,4Institute of Biochemistry, Magadh University, Bodh-Gaya, India \\ ${ }^{2}$ Department of Chemistry, J. J. College, Gaya, India
}

\begin{abstract}
Mangoes are naturally very rich subtropical fruit with unique flavor, fragrance, taste and health promoting compounds like phytochemicals which consists of carotenoids, phenolic, alkaloids, nitrogen containing compounds and organo sulphur. Out of which carotenoids and phenolic are most important healthy ingredients. The different cultivars popularly available in Bihar are - Amrapali, Maldah, Jardalu and Sinduri. Amrapali and Maldah cultivars are very popular in North Bihar as well as Central Bihar while Jardalu is famous particularly in Bhagalpur (Vikramshila region). Sinduri cultivar of mango is common in South Bihar. All the four cultivars of mango were collected and investigated for carotenoids, phenolics, reducing sugar and other parameters in the peels and pulps of green mature (GM) stage and fully ripe (FR) stages of all the cultivars. Carotenoids contents and phenolic contents in all the four cultivars of mangoes were analyzed by solvent extraction method followed by spectrophotometric method. Among the different mango cultivars Amrapali contains the highest amount of carotenoids which is about $27 \mathrm{mg} / 100 \mathrm{~g}$ followed by Maldah containing about 22.34 mg/100g. Jardalu and Sinduri cultivars contains $20.45 \mathrm{mg} / 100 \mathrm{~g}$ and $21.67 \mathrm{mg} / 100 \mathrm{~g}$ respectively. With respect to total phenolic again Amrapali cultivar is found to be the richest with $78 \mathrm{mg}$ GAE $/ 100 \mathrm{~g}$ in its peel. Maldah and Jardalu have almost the same content of phenolics with $40 ; 44 \mathrm{mg} \mathrm{GAE} / 100 \mathrm{~g}$ and $300 ; 305.49 \mathrm{mg}$ GAE $/ 100 \mathrm{~g}$ of their pulp and peels respectively. The Sinduri cultivar has been found to possess the lowest content of total phenolics with $30.29 \mathrm{mg} \mathrm{GAE} / 100 \mathrm{~g}$ and $269.85 \mathrm{mg} \mathrm{GAE} / 100 \mathrm{~g}$ of its pulp and peels respectively. For all the cultivars peels were found with greater contents of phenolics than that of pulp but for Amrapali and Maldah the carotenoids content were found less in their peels than their pulp, but for the rest two varieties the carotenoids content is slightly greater in peels than pulp.
\end{abstract}

Keywords: Carotenoids, Phenolics, Phytochemical.

\section{Introduction}

Phytochemicals are highly bioactive compounds in fruits, vegetables, grains and other plant. Particularly carotenoids and phenolics present in food are powerful antioxidant [1]-[3]. Liu [4] has broadly classified antioxidative phytochemicals in plants and fruits as carotenoids, phenolics, alkaloids, nitrogen containing compounds and organo sulphur compound as given in figure 1.

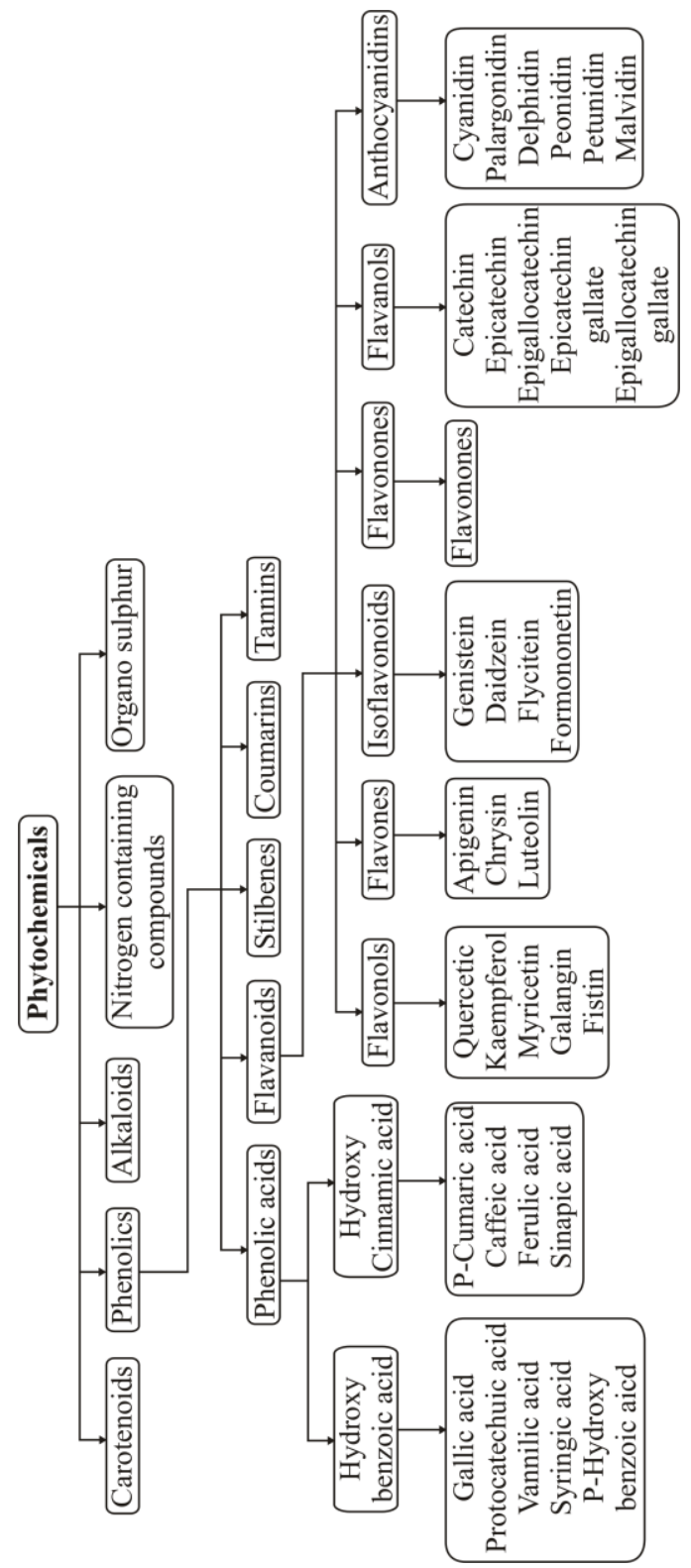

Fig. 1. Phytochemicals 
Mangoes have been reported as wonderful source of $\beta$ carotene, Vitamin C, phenolics and dietary fiber [5]. Vitamin A deficiency is a major problem in our country causing childhood blindness, retarded growth, impaired reproduction, inadequate RBC production, infections etc and carotenoids having provitamin A have amazing benificial effect on human health [6], [7]. Galic acid and hydrolysable tannins are particularly found as major phenolic compounds in mango [8], [9]. Recent studies on mangifera indica L. reveal antioxidative and antiproliferative activities, tyrosinase inhibitory activity, in haemorrhagic activity and antidermonacrotic activities of pulp, peel and seed kernel of different cultivars of mangoes [10]-[13]. S. Kittiphoan [14] has published a review on the utilization of mango seed showing the presence of several minerals, amino acid and other valuable nutritional chemicals in the mango seed kernel and hence it can be used as functional food ingredient. Apart from these extraordinary human health activities mango seed kernel extract has also exhibited antisnake venoms and potent antibacterial activities [15], [16]. The antioxidant properties of pulp and peels of mango or any other fruits and vegetables are associated with the presence of phytochemicals including phenolic, flavanoid and anthocymins in the mango. In last decade the critical evaluation of these phytochemicals in fruits and vegetable have been reported in literature [17]-[20]. the level of antioxidant activity of phytochemicals are greatly affected by the genetics, location and environment growing condition like moisture, fertilization, pest and disease burden as well as processing methods and storage of fruits [21], [22]. The literature is thus full of studies made on pulp, peel and seed kernel of different varieties of mangoes. However, the report on the comparative study of phytochemical content in different cultivars of mango in Bihar is quite scanty. Hence the present study was contemplated to evaluate and compare the phytochemical contents in the pulp and peel of four different cultivars of mango which is Amrapali, Maldah, Jardalu and Sinduri popularly four in Bihar.

\section{Study Areas}

Different cultivars of mangoes (Mangifera indica L.) are popular in different parts of Bihar and hence the study area covers the whole Bihar. Mango fruits of different cultivars viz. Amrapali, Maldah, Jardalu and Sinduri were harvested from Amgola Market Muzaffarpur, Digha Market of Patna, TM university campus, Bhagalpur and Kedarnath Market, Gaya respectively. About 20 fruits of green matured stage GM of each cultivars were used as sample. Sample were divided into two equal parts: first part consisting of 1 mango of each cultivar were analyzed in GM stage and rest part were rapped in paper and well covered by paper for ripening. After allowing the GM mangoes to ripen at room temperature for three days or until $100 \%$ yellow colour of fully ripe (FR) stage was reached. After cleaning all the different cultivars of mangoes they were separated into peels, pulps and seed kernel, their small cut pieces were stored in polyethylene terephthalate in freezer for further analysis.

The various parts of mangoes samples from four cultivars were analysed for physicochemical characteristic like moisture content by the reported method [23], colour using colorimeter, $\mathrm{pH}$ using $\mathrm{pH}$ meter by reported method [24]. For the estimation of other parameters at first ethanolic extract from mango peels and pulp was prepared for which dried samples of different mangoes were taken and about 200 grams of finely chopped

Table 1

Values of different Physiochemical parameters of all the four cultivars of Mangoes of Bihar

\begin{tabular}{|c|c|c|c|c|c|c|}
\hline Mango Cultivar & pH & Moisture Content & Colour & Reducing Sugar & $\begin{array}{c}\text { Total Phenolics } \\
\text { GAE/100gm }\end{array}$ & $\begin{array}{c}\text { Total Carotenoids } \\
\mathrm{mg} / \mathrm{kg} / \mathbf{1 0 0 g m}\end{array}$ \\
\hline $\begin{array}{l}\text { 1. Amrapali } \\
\text { A. Green Mature (GM) } \\
\text { (a) Peel } \\
\text { (b) Pulp }\end{array}$ & $\begin{array}{l}5.00 \\
4.22 \\
\end{array}$ & $\begin{array}{l}62.31 \% \\
70.87 \% \\
\end{array}$ & $\begin{array}{l}\text { Green } \\
\text { Off white }\end{array}$ & $\begin{array}{l}\text { Negligible } \\
15.32(a)\end{array}$ & $\begin{array}{l}135.35 \\
40.00\end{array}$ & $\begin{array}{l}\text { Negligible } \\
\text { Negligible }\end{array}$ \\
\hline $\begin{array}{l}\text { B. Fully Ripe (FR) } \\
\text { (a) Peel } \\
\text { (b) Pulp } \\
\end{array}$ & $\begin{array}{l}5.71 \\
6.26 \\
\end{array}$ & $\begin{array}{l}71.15 \% \\
76.32 \% \\
\end{array}$ & $\begin{array}{l}\text { Yellowish green } \\
\text { Yellow }\end{array}$ & $\begin{array}{l}7.32(a) \\
19.00(a)\end{array}$ & $\begin{array}{l}335.89 \\
78.00\end{array}$ & $\begin{array}{l}29.31 \\
27.00\end{array}$ \\
\hline $\begin{array}{l}\text { 2. Maldah } \\
\text { A. Green Mature (GM) } \\
\text { (a) Peel } \\
\text { (b) Pulp }\end{array}$ & $\begin{array}{l}4.87 \\
4.00\end{array}$ & $\begin{array}{l}67.50 \% \\
70.82 \%\end{array}$ & $\begin{array}{l}\text { Green } \\
\text { Off white }\end{array}$ & $\begin{array}{l}\text { Negligible } \\
14.35(a)\end{array}$ & $\begin{array}{l}139.00 \\
25.00\end{array}$ & $\begin{array}{l}\text { Negligible } \\
\text { Negligible }\end{array}$ \\
\hline $\begin{array}{l}\text { B. Fully Ripe (FR) } \\
\text { (a) Peel } \\
\text { (b) Pulp }\end{array}$ & $\begin{array}{l}5.62 \\
6.32\end{array}$ & $\begin{array}{l}71.00 \% \\
74.92 \%\end{array}$ & $\begin{array}{l}\text { Yellowish green } \\
\text { Yellow }\end{array}$ & $\begin{array}{l}10.00(a) \\
23.12(a)\end{array}$ & $\begin{array}{l}300.00 \\
40.00\end{array}$ & $\begin{array}{l}24.12 \\
22.34\end{array}$ \\
\hline $\begin{array}{l}\text { 3. Jardalu } \\
\text { A. Green Mature (GM) } \\
\text { (a) Peel } \\
\text { (b) Pulp }\end{array}$ & $\begin{array}{l}4.88 \\
4.12\end{array}$ & $\begin{array}{l}60.15 \% \\
68.92 \%\end{array}$ & $\begin{array}{l}\text { Green } \\
\text { Off white }\end{array}$ & $\begin{array}{l}\text { Negligible } \\
14.32 \text { (a) }\end{array}$ & $\begin{array}{l}109.86 \\
24.00\end{array}$ & $\begin{array}{l}\text { Negligible } \\
\text { Negligible }\end{array}$ \\
\hline $\begin{array}{l}\text { B. Fully Ripe (FR) } \\
\text { (a) Peel } \\
\text { (b) Pulp }\end{array}$ & $\begin{array}{l}5.35 \\
6.00\end{array}$ & $\begin{array}{l}72.00 \% \\
78.31 \%\end{array}$ & $\begin{array}{l}\text { Yellowish green } \\
\text { Yellow }\end{array}$ & $\begin{array}{l}5.53(a) \\
17.78(a)\end{array}$ & $\begin{array}{l}305.00 \\
44.00\end{array}$ & $\begin{array}{l}15.36 \\
20.45\end{array}$ \\
\hline $\begin{array}{l}\text { 4. Sinduri } \\
\text { A. Green Mature (GM) } \\
\text { (a) Peel } \\
\text { (b) Pulp }\end{array}$ & $\begin{array}{l}4.70 \\
4.18\end{array}$ & $\begin{array}{l}57.42 \% \\
62.34 \% \\
\end{array}$ & $\begin{array}{l}\text { Reddish green } \\
\text { Off white }\end{array}$ & $\begin{array}{l}\text { Negligible } \\
12.55(\mathrm{a})\end{array}$ & $\begin{array}{l}98.76 \\
20.00\end{array}$ & $\begin{array}{l}2.86 \\
\text { Negligible }\end{array}$ \\
\hline $\begin{array}{l}\text { B. Fully Ripe (FR) } \\
\text { (a) Peel } \\
\text { (b) Pulp }\end{array}$ & $\begin{array}{l}5.46 \\
6.32\end{array}$ & $\begin{array}{l}71.31 \% \\
74.35 \%\end{array}$ & $\begin{array}{l}\text { Reddish green } \\
\text { Yellow }\end{array}$ & $\begin{array}{l}4.84(a) \\
16.25(a)\end{array}$ & $\begin{array}{l}269.85 \\
30.29\end{array}$ & $\begin{array}{l}17.42 \\
21.67\end{array}$ \\
\hline
\end{tabular}

Where (a) $=$ mg glucose per $\mathrm{g}$ of sample 
samples were homogenized with $100 \mathrm{ml}$ of $95 \%$ ethanol at high speed for five minutes. Thereafter the homogenates were placed in water bath maintained at $80^{\circ} \mathrm{C}$ for an hour with an occasional shaking. It was cooled at room temperature and the supernatants were recovered and filtered through Whatmann filter paper no. 4 and it was stored at $0^{\circ} \mathrm{C}$ for further analysis.

\section{A. Determination of total phenolic content}

All the chemicals used were of analytical grade. The total phenolic content (TPC) was determined by Folin-Ciocalteu reagent using an external Calibration curve with Galic Acid for its quantification and the results were expressed milligram Galic Acid Equivalents (GAE) per gram of the sample [25], [26].

\section{B. Carotenoids extraction and quantification}

For the quantification of carotenoids, it was first extracted from the pulp and peels of GM and FR stages of all the four mango cultivars by samponification of Panfili et al., [27]. It was quantified by the combination of normal and reverse phase HPLC method. The element obtained from HPCL in normal hexane was used for the estimation of total carotenoids in it on spectrophotometer at $450 \mathrm{~nm}$ wavelength using a $1 \mathrm{~cm}$ cell.

\section{Reducing Sugar}

The reducing properties of the different cultivars of mangoes is associated with the presence of potential aldehyde or keto group of certain types of carbohydrates present in the pulp and peels of mangoes. The reducing sugar of all the four cultivars of mangoes in both GM and FR stages was determined by the method of Neilson [28] which is based on absorbance at 520 $\mathrm{nm}$ of coloured complex between copper oxidized sugar and arsinomolybdate. It is expressed in milligram glucose per gram of sample.

\section{Result and Discussion}

In the present study the four different cultivars of mangoes which is Amrapali, Maldah, Jardalu and Singuri popularly found in different parts of Bihar state have been analyzed for different parameters like $\mathrm{pH}$, moisture content (MC), Reducing Sugar (RS), Total phenolics and Total carotenoids and their comparison has been presented in table 1 and 2 .

\section{Physicochemical Properties}

$p H$ : The $\mathrm{pH}$ of all the four mango cultivars at GM stage and FR stage have been presented in table 1, which reveals that both the peel and pulp of GM stage of mangoes of all the four varieties record less $\mathrm{pH}$ than that of fully ripe mangoes. The second significant information is also unveiled from the study that in GM stage of all the four cultivars of mango the $\mathrm{pH}$ of peel is found greater than that of pulps while for FR stage of all the varieties the pulp recorded higher $\mathrm{pH}$ than peels. It shows that in GM stage of all the mangoes the pulp has a higher acidity than the peels. The increase in $\mathrm{pH}$ of both pulp and peels of GM mangoes to that of FR mangoes reveals the decrease in acidity of peels and pulps with ripening of the mangoes. The result is in good agreement with the reported values of $\mathrm{pH}$ in different
Table 2

Colorimetric values of Peels and Pulps for all the four cultivars in GM and FR

\begin{tabular}{|l|l|l|l|}
\hline \multicolumn{1}{|c|}{ Mango Cultivar } & \multicolumn{3}{|c|}{ Colour Parameter } \\
\cline { 2 - 4 } & L* value & $\mathbf{a}^{*}$ value & $\mathbf{b}^{*}$ value \\
\hline 1. Amrapali & & & \\
A. Green Mature (GM) & & & \\
(a) Peel & 48 & 13.47 & 16.25 \\
(b) Pulp & 52 & 3.12 & 17.45 \\
\hline B. Fully Ripe (FR) & & & \\
(a) Peel & 62 & 2.96 & 47.51 \\
(b) Pulp & 73.92 & 1.54 & 59.69 \\
\hline 2. Maldah & & & \\
A. Green Mature (GM) & & & \\
(a) Peel & 45 & 12.01 & 30.62 \\
(b) Pulp & 50 & 5.83 & 19.12 \\
\hline B. Fully Ripe (FR) & & & \\
(a) Peel & 72.34 & 03.16 & 44.86 \\
(b) Pulp & 78.92 & 3.32 & 41.04 \\
\hline 3. Jardalu & \multicolumn{3}{|}{} \\
A. Green Mature (GM) & & & \\
(a) Peel & 50.53 & 17.25 & 27.38 \\
(b) Pulp & 54.39 & 6.84 & 22.56 \\
\hline B. Fully Ripe (FR) & & & \\
(a) Peel & 71.91 & 3.16 & 46.78 \\
(b) Pulp & 73.15 & 8.09 & 56.32 \\
\hline 4. Sinduri & & & \\
A. Green Mature (GM) & 45.59 & 8.65 & 23.00 \\
(a) Peel & 54.86 & 6.82 & 23.50 \\
(b) Pulp & & & \\
\hline B. Fully Ripe (FR) & 60.67 & 2.89 & 37.69 \\
(a) Peel & 72.98 & 0.75 & 49.44 \\
(b) Pulp & & & \\
\hline
\end{tabular}

parts of different cultivars of mangoes [29].

Moisture Content: The moisture content of the different parts of mangoes is found to have varied significantly between the different cultivars and the maturity stages. Moisture content of peels in GM stage of mango has been found $57.42 \%$ to $67.50 \%$ which is less than its pulp that varies from 62.34 to $70.82 \%$. After ripening each cultivar of mangoes have recorded higher percentage of moisture content both in peels and pulps, in peels it runs from $71.00 \%$ to $72.00 \%$ in peels and $74.35 \%$ to $78.31 \%$ in pulp. However, the moisture content of the pulps and peels of all the cultivars tested was found within the range of the values previously reported [30].

Reducing Sugar: The peels of all the four varieties of mangoes show negligible amount of reducing sugar in green mature stage. But their pulps recorded reducing sugar varying from 12.55 to $15.32 \mathrm{mg}$ glucose per gram of sample with highest in the pulp of GM Amrapali $15.32 \mathrm{mg}$ glucose per gram of sample followed by Maldah with $14.35 \mathrm{mg}$ glucose per gram of sample. The least value of reducing sugar is recorded by GM Sinduri cultivar with $12.55 \mathrm{mg}$ glucose per gram of sample. After ripening the pulp of all the four cultivars recorded higher value of reducing sugar which is highest for Maldah (23.12 mg glucose per gram of the sample) followed by Amrapali (19.00 $\mathrm{mg}$ glucose per gram of sample). Jardalu recorded $17.78 \mathrm{mg}$ glucose per gram sample while it $16.25 \mathrm{mg}$ glucose per gram of sample for Sinduri in FR stage thus the reducing sugar content varies significantly in the pulp of FR stage of these mangoes in the order Maldah > Amrapali > Jardalu > Sinduri. Unlike the peels of GM mangoes, the peel of FR mangoes of each variety recorded considerable amount of reducing sugar which, however also show the same order i.e. Maldah (10.00) > 
Amrapali (7.32) > Jardalu (5.53) > Sundari (4.84). From these data it may be concluded that there is certain increase in carbohydrate content in pulp but it depends on the different varieties of the mango [31].

Total Phenolics: The total phenolics in the peels and pulps of GM and FR stages of different mango cultivars have been shown in table-1. In GM mango peels of different mangoes cultivars varies from 98.76 to $39.00 \mathrm{GAE}$ per 100 grams of sample while in pulps of GM mango cultivars it varies from 20.00 to $40.00 \mathrm{GAE}$ per 100 grams of the sample. In GM stage the highest value of phenolics has been recorded in the peels of Maldah while the lowest value goes to Sinduri cultivar but in the case of pulp of GM of different varieties of mangoes the phenolic contents in maximum in Amrapali while it minimum again in Sinduri. In all the varieties of mangoes in GM stage the phenolic content in peels is much greater than that of pulp. The similar trend has also been reported by Ajila et al., [32] and Monaco et al[33]. On ripening in all the four cultivars of mangoes there is significant enhancement of phenolic content both in peels and pulps. In FR stage of mangoes the phenolics content ranges from 335.89 to $269.85 \mathrm{GAE}$ per gram of the sample the highest value is recorded in the peels of FR Amrapali followed by the peels of FR Jardalu (305.00 GAE/ $100 \mathrm{~g}$ ) and peels of FR of Maldah cultivar records very close (300 GAE/100g) to the Jardalu. The Sinduri varieties reports $269.85 \mathrm{GAE} / 100 \mathrm{~g}$ of phenolic content which is lowest among four varieties. The FR pulp of all the four varieties of mangoes have been found to have recorded phenolic content values from 78.00 (in Amrapali) to 30.29 GAE/100g in Sinduri again Maldah and Jardalu have been found to have recorded phenolic contents very close to each other that is 40.00 and $44.00 \mathrm{GAE} / 100 \mathrm{~g}$ respectively. In FR stage also like the GM stage of mango the phenolic content in peels has been observed much greater than that of pulp. Thus it may be concluded that the content of total phenolics is higher in mango peels than in pulp at both the GM and FR stages of mangoes which is in a good accord with the earlier reported studies [34], [35]. Higher phenolic content has also been reported in pomegranate and apple peels as compared to their pulp [36], [37].

Total Carotenoids: The total carotenoids in the peel and pulp of all the four mango cultivars in GM stage has been found negligibly small (less than $1.00 \mathrm{mg}$ percent) except sinduri which records $2.86 \mathrm{mg}$ per 100 grams of the sample in its peels, perhaps which is responsible for its red green colour in GM stage. The FR stage of all the four varieties show significant variation in their total carotenoids content in both their peels and pulps. The peels of Amrapali and Maldah possess more carotenoids i.e. 29.31 and $24.12 \mathrm{mg}$ per $100 \mathrm{~g}$ respectively while the peels of Jardalu and Sinduri in FR stage contain relatively less amount of carotenoids i.e. 15.36 and 17.42 $\mathrm{mg} / 100 \mathrm{~g}$ respectively. In the pulp, the carotenoids value varies from $20.45 \mathrm{mg} / 100 \mathrm{~g}$ in Jardalu to $27.00 \mathrm{mg} / 100 \mathrm{~g}$ in Amrapali. Thus the pulp of Amrapali contains the highest value of carotenoids followed by Maldah $(22.34 \mathrm{mg} / 100 \mathrm{~g})$ and then comes Sinduri $(21.64 \mathrm{mg} / 100 \mathrm{~g})$. In the case of Amrapali and Maldah the carotenoids value decreases from peel (29.31 and $24.12 \mathrm{mg} / 100 \mathrm{~g}$ ) to 27.00 and $22.34 \mathrm{mg} / 100 \mathrm{~g}$ respectively while the value increases from 15.36 and $17.42 \mathrm{mg} / 100 \mathrm{~g}$ to 20.45 and $21.67 \mathrm{mg} / 100 \mathrm{~g}$ in Jardalu and Sinduri cultivars. Thus it's obvious that carotenoids are evenly distributed among varieties of mangoes [38]. Similar variation in carotenoid content has been reported for different varieties like chausa, Fazli, Raspuri, Badami etc. [39].

Colour Parameter: The colorimetric values are expressed in terms $\mathrm{L}^{*}, \mathrm{~A}^{*}, \mathrm{~B}^{*}$ values which has been mentioned in table-2 for the peels and pulps in GM stage and FR stage of all the four cultivars i.e. Amrapali, Maldah, Jardalu and Sinduri. L* value is the measurement of shining or luminocity which may vary from 0 for black to 100 for white. The positive value of $A^{*}$ indicates in the direction of redness while negative $A *$ towards greenness. In the case of $\mathrm{B}^{*}$ positive $\mathrm{B}^{*}$ value indicates towards yellowness while its negative value indicates towards blueness. The perusal of the values of colorimetric parameter clearly indicates that the $\mathrm{L}^{*}$ value of GM stage of all the four varieties falls around 50 showing their good shining in GM stage but with ripening in all the four varieties the $\mathrm{L}^{*}$ values increase and go to 60 and above for both peel and pulp it clearly indicates that shining of all the four varieties studied here gets enhanced with ripening. The $\mathrm{A}^{*}$ values of GM mangoes of all the four varieties is negative which is indicative of their green colour in GM stage however on ripening the $A *$ value either becomes less negative or positive. It indicates the change of colour from green in GM stage to yellow or red in FR stage for both peels and pulps in all the four varieties. Similarly, the $\mathrm{B}^{*}$ value of all the four varieties increases from peel and pulp of GM stage to that of FR stage which are responsible for change in their colour to yellow or red or purple on ripening. The positive value of $A^{*}$ and $\mathrm{B}^{*}$ with higher value of $\mathrm{L}^{*}$ are indicative of higher content of carotenoids in Amrapali and Maldah cultivars [40].

\section{Conclusion}

From the present studies of four cultivars of mangoes popularly found in different region of Bihar state revealed that all the four cultivars contain the appreciable amount of various phytochemicals like reducing sugar, total phenolics, carotenoids in their peels and pulps in both GM and FR stages. However, there has been a significant variation in different parameter for all the four cultivars. The variation has also been considerably found from peels to pulps in both GM and FR stages and from GM stage to FR stage. Some phytochemical like total phenolics have been found more in peels than pulp in both the GM and FR stages. In Amrapali and Maldah the carotenoid content has been observed to have decreased from peels to pulp in FR stage while for Jardalu and Sinduri cultivars the carotenoids content gets increased from peels to pulp. On the basis of the present studies all the four cultivars have represented a potential source of natural phenolics, carotenoids and reducing sugar but Amrapali and Maldah have been found the richer source of nutrition.

\section{References}

[1] J. C. Barreto, M. T. S. Trevisan, W. E. Hull, G. Erben, E. S. De, Brito, B. Pfundustin, G. Wultele, B. Spiejelhalder and R. W. Owen, (2008), "Characterization and quantization of polyphenolic compound in bark, 
kernel, leaves and peel of mango (Mangifera indica L.)", J. Agri. Food. Chem., 56 (14), 5599-5610.

[2] M. Masibo and Q. He, (2008), "Major mango polyphenols and their potential significance to human health", Comprehensive Review of Food Sci. and Food Safety, 7, 309-319.

[3] H. Kim, J. Y. Moon, H. Kim, D. S. Lee, M. Coo, H. K. Choi, Y. S. Kim, A. Mosaddik and S. K. Cho, (2010), "Antioxidant and antiproliferative activities of mango (Mangifera indica L.) flesh and peel", Food Chem., 121, 429-436.

[4] R. H. Liu, (2004), "Potential synergy of phytochemicals in cancer prevention mechanism of action", J. of Nutr., 134, 3479s-3485s.

[5] S. M. R. Ribeiro, L. C. A. Barbosa, J. H. Quiroz, M. Knodler and A. Schieber, (2008), "Phenolic compounds and antioxidant capacity of Brazalian mango (Mangifera indica L.) varieties", Food Chem., 110, 620626.

[6] I. Gouado, F. J. Schweigert, R. A. Ejoh, M. F. Tchouanguep and J. V. Camp, (2007), "Systematec levels of carotenoids from mangoes and papaya consumed in three forms (juice, fresh and dry slice)", Euro. J. Clin. Nutr., 61 (10), 1180-1188.

[7] H. E. Khoo, K. N. Prasad, A. Ismail and N. M. Esa, (2010), "Carotenoids from Mangifera Pajang and their antioxidant capacity", Molecules, 15, 6699-6712.

[8] Y. Y. Soog and P. J. Barlow, (2004), "Antioxidant activity and phenolic content of selected fruit seed", Food Chem., 88, 411-417.

[9] Y. Y. Soog and P. J. Barlow, (2006), "Quantification of Galic acid and Ellagic acid from longan seed and mango (Mangifera indica L.), kernal and their effect on antioxidant activity", Food Chem., 97, 524-530.

[10] O. Patthamakamokpom, P. Puwastien, A. Nitithamyong and P. P. Sirichakwal, (2008), "Change of antioxidant activity and total phenolic compounds during storage of selected fruit", J. Food. Compos. Analy., 21, 241-248.

[11] C. M. Ajila, M. Aalami, K. Leelavathi and U. J. S. P. Rao, (2010), "Mango peel powder - A potential source of antioxidant and dietary fibre in macroni preparation", Innov. Food Sci. Emer. and Techno., 11 (1), 219224.

[12] S. Poovarodom, R. Haruenkit, S. Vearasilp, J. Namiesnik, M. Vikrova, O. Maratincova, A. Ezra, M. Suhaj, P. Ruamsuke and S. Gorinstein, (2010), "Comparative characterization of durian mango and avocardo", Int. J. Food Sci. Technol., 45, 921-929.

[13] P. Maisuthisakul and M. H. Gordon, (2009), "Antioxidant and tyrosinase inhibitory activity of mango seed kernel byproduct", Food Chem., 117, 332-341.

[14] S. Kittiphoan, (2012), "Utilization of mango queed", Int. Food Resea. J., 19 (4), 1325-1335.

[15] J. Leanpolchareanchai, P. Pithayanukel, R. Bavovada and P. Saparpakorn, (2009), "Molecular docking studies and antienzymatic activities of thai mango seed kernal extract against snake venoms", Molecules, 14, 14041422 .

[16] S. Khammuang and R. Sarnthima, (2011), "Antioxidant and antibacterial activities of selected varieties of thai mango seed extract", Pakistan J. of Pharmaceutical Sci., 24, 37-42.

[17] M. N. Clifford, (2000), "Anthoxymins, nature accurance and dietary burden", J. Sci. Food Agri, 80, 1063-1072.

[18] J. Sun, Y. F. Chu, X. Wu, R. H. Liu, (2002), "Antioxidant and aniproliferative activities of common fruit", J. Agri. Food Chem., 50, 7449-7454.

[19] R. L. Prior, (2003), "Fruits and vegetables in the preventation of cellular oxidative damage", Am. J. Clin. Nitr., 78, 570-578.

[20] F. C. Stintozing and R. Carle, (2004), "Functional properties of anthocymines and Betalains in plants food and in human nutrition", Trends Food Sci. Technol., 15, 1938.
[21] V. Dewanto, X. Z. Wu, K. K. Adom and R. H. Liu, (2002), "Thermal processing enhances the nutritional value of tomatoes by increasing total antioxidant activity", J. Agric. Food Chem., 50, 3010-3014.

[22] L. F. Reyas, J. C. Miller and L. C. Zevalos, (2004), "Environmental condition influence the content and yield of anthoxymines and and total phenolics in purple and red flesh during their development", Am. Potato Research, 81, 187-193.

[23] AOAC, (2000), "Official method of analysis of AOAC international seventeenth ed.", Assiciation of official analytical chemistry, Washington, Aspen Publishers.

[24] J. P. Chan, C. Y. Tai and B. H. Chen, (2007), "Effects of different drawing treatments on the stability of carotenoids in Taiwanic mango", Food Chem., (103), 1005-1010.

[25] V. L. Singleton and J. A. Rossi, "Coloriemetry of total phenolics with phosphomolybdic - phosphungstic acid reagents", J. Enol. Vitic., 3, 144158.

[26] V. L. Singleton, R. Orthofer and R. M. L. Raventos, (1999), "Analysis of total phenols other oxidation substrates and antioxidants by means of folin Ciocalter Reagent", Methods in Enzymology, 299, 152-178.

[27] G. Panfili, A Fratianni and M. Irano, (2004), "Improved normal phase high performance liquid chromatography procedure for the determination of carotenoids in cereals", J. Agric. Food Chem., 52, 6373-6377.

[28] S. S. Neilson, (1998), Food analysis $2^{\text {nd }}$ ed. Maryland, Aspen Publishers

[29] P. Pinsirodom, R. Taprap and T. Parinyapatthanafoot, (2008), "Antioxidant activity and phenolic acid composition in different parts of selected cultivars of mangoes in Thailand", Int. Food Resea. J., 25(4), 1435-1443.

[30] L. G. Po, (2007), "Major tropical fruit and products - Banana, mango and pineapple", Handbook of food product manufacturing, New Jersey, John Wiley and Sons, P - 815-845.

[31] S. Poovarodom, R. Haruenkit, S. Verasilp, J. Namieshik, M. Cvikrova, O. Martincova, A. Ezra, M. Suhaz, P. Ruansuke and S. Gorinstein, (2010), "Comparative characterization of mango and avocardo", Int. J. Food Sci. Technol., 45, 921-929.

[32] C. M. Ajila, S. G. Bhat and U. J. S. Prasada Rao, (2007), "Valuable component of raw and ripe peels from two indian mango varieties", Food Chemistry, 102, 1006-1011.

[33] K. A. Monaco, S. M. Costa, M. R. Uliana and G. P. P. Lima, (2014), "Sanitizers effect in mango pulp and peel antioxidant compounds", Food and Nutrition Science, 5, 929-935.

[34] M. Ueda, K. S. Sasaki, N. Utsunimiya, K. Inaba and Y. S. Bayashi, (2000), "Variation of total polyphenol and polyphenol oxidase activity during maturation of mango fruits cultured in plastic green house", Food Sci. Technol. Res., 6, 299-305.

[35] S. M. R. Ribeiro, H. J. Queiroz, M. E. L. R. Queiroz, F. M. Campos and H. M. P. Sant Ana, (2007), "Antioxidant in mango pulp", Plant foods for human nutrition, 62, 13-17.

[36] Y. Li, C. Guo, J. Yang, J. Wui, J. Xu and S. Chang, (2006), "Evaluation antioxidant properties of pomegranate peel extract in comparison with pomegranate pulp extract", Food Chemistry, 96, 254-260.

[37] P. D. Drogoudi, Z. Michailidts and G. Pantelidis, (2008), "Peel and flesh antioxidant content and harvest quality characteristics of seven apple cultivars", Journal of Scintia Horticulture, 115, 149-153.

[38] M. Nehra and A. Sharma "Comparison of total carotenids content, Asocorbic acid and radical scavaning activity of three indian mango varieties", Int. J. Sci. Res., 1, 86, 7.

[39] C. M. Ajila, K. A. Naidu, S. G. Bhat and U. J. S. Prasada Rao, (2007), "Bioactive compound and oxidant potential of mango peel extract", Food Chem., 105, 982-988.

[40] J. J. O. Paz, F. M. Yahia and A. G. Bejar, (2007), "Identification and quantification of Xanthophylls, esters carotenes and tocopherols in the fruit of seven mexican mango cultivars", J. Agri. Food Chem., 55, 66286635. 